\title{
Groundwater, Graves and Golf: Layers of Heritage Tourism on a Fiji Resort Island
}

\author{
Dirk H. R. Spennemann
}

Citation: Spennemann, D.H.R. Groundwater, Graves and Golf: Layers of Heritage Tourism on a Fiji Resort Island. Sustainability 2021, 13, 5863. https://doi.org/10.3390/ su13115863

Academic Editor: Stephen Royle

Received: 6 May 2021

Accepted: 20 May 2021

Published: 23 May 2021

Publisher's Note: MDPI stays neutral with regard to jurisdictional claims in published maps and institutional affiliations.

Copyright: (C) 2021 by the author. Licensee MDPI, Basel, Switzerland. This article is an open access article distributed under the terms and conditions of the Creative Commons Attribution (CC BY) license (https:// creativecommons.org/licenses/by/ $4.0 /)$.
Institute for Land, Water and Society, Charles Sturt University, Albury, NSW 2640, Australia; dspennemann@csu.edu.au

\begin{abstract}
While island resorts in the South Pacific are primarily marketed as sun, sea and sand destinations, cultural dimensions value-add to and diversify the product for mixed audiences. Resort developments require, at minimum, the compliance with legally mandated environmental standards and adherence to national employment legislation. Socio-culturally and environmentally sustainable tourism concepts should exceed mandated environmental standards and be characterised by a close involvement with and respect for the expectations of local host communities who may hold land and/or traditional usufruct rights. But do resort developments comply? Using an example of a resort established on free-hold land during the pioneering days of resort development in Fiji, the aim of this paper is to provide a deliberation of the tension between organic resort development and sustainable tourism on private land. It will show that, where cultural and environmental planning controls were absent, development not only could progress unfettered but also that changes to tourism philosophies are not necessarily reflected in changes to a resort. The island of Malolo Lailai (Viti Levu, Fiji) has a rich and multi-layered history and heritage (Fijian, European and Chinese plantations, resort development) that provides an opportunity to value-add to the tourist experience. In reality, however, the ongoing resort development extinguishes past histories in favour of a postoccupation, twentieth-century colonial settler narrative, where heritage sites are merely allowed to co-exist provided they do not impact on resort development objectives. It demonstrates that, in the absence of external regulatory controls, the resort owner's philosophy dominates and shapes the tourist experience.
\end{abstract}

Keywords: tourist resort development; sustainable tourism; heritage tourism; heritage interpretation

\section{Introduction}

The last quarter of the twentieth century saw a boom in the development of beach and island resorts in many parts of the world, driven by affluent residents of first-world countries, as well as of emergent markets in South Korea, China and India. The primary drivers were the classic 3S (sun, sea and sand) tourism [1,2], supported by intensive and extensive marketing [3]. This encompassed the whole range of accommodation and experience options, ranging from mass market resorts operated by hotel chains to off-grid, Robin Crusoe-style beachcomber accommodation [4,5]. For several island destinations, the $3 S$ tourism remains a major focus of marketing and development [6,7]. While the national economy of many small island states welcomed this development, hoping that tourism would lead to poverty alleviation [8], national tourism boards became increasingly concerned that an over-reliance of the three "Ss" might expose their nation's destination to competitors in novel locations [9,10]. As the market became saturated and/or the clientele's expectations changed [11], resorts, as well entire destinations, had to adapt $[4,12,13]$.

Not surprisingly, national tourism boards in the Pacific Islands looked at value-adding to the offerings by expanding nature-based opportunities in niche markets, such as diving or surfing $[14,15]$ but also by capitalizing on the opportunities presented by the local culture and by the interpretation of Indigenous, colonial and World War II (military) places 
both on land [16-21] and underwater [22,23]. This effort was supported and promoted by airlines $[24,25]$ and by private publishing enterprises $[26,27]$. Since then, heritage tourism has diversified both as a concept and in terms of market differentiation [28], ranging from the traditional consumptive (e.g., site visits) [29] to participatory and immersive experiences $[29,30]$.

Fiji was no different in that regard [31-35]. In his seminal study "Creating Resort Islands", Brian King examined resort developments in Fiji's Mamanuca Islands and contrasted them with resort developments in Australia [9]. Building on earlier work [32], King argued that resort developments on the Mamanuca Islands had the potential to diversify their offerings and focus, inter alia, on the opportunities of cultural heritage tourism as facilitated by the archaeological and historical sites as well as the traditional, living heritage [9].

In parallel, the tourist market has become more diversified and also more discerning, increasingly concerned about the environmental and social impact they may cause. The last quarter of the twentieth century saw the rise of the concepts of sustainable tourism and ecotourism. For tourism to be sustainable in the longer term, operations need to meet the "triple bottom line" of being socio-culturally, environmentally and economically sustainable [36,37]. The underlying tenet was that the development should benefit the host community and aid in poverty alleviation and not just benefit foreign-owned corporations $[34,38]$. There is a large body of literature that considers the delivery of sustainable tourism on a global scale [39-41], as well as on a regional basis, such as in the Pacific Islands [42-44]. Resort developments have been the focus of several studies [45,46], inter alia, in the Pacific [9].

Fundamentally, for tourism to be fully sustainable, it must not be detrimental to or exploitive of the assets it relies on, be they the physical, the social or the cultural environment $[40,47]$. In some of these, resort developers are governed by legally defined externalities, while in others, resort developers are only subject to their own ideology and philosophy. While resort development, overall, is subject to national policy settings [48], the environmental impact of a specific resort development, i.e., its infrastructure and the management of utilities (e.g., freshwater procurement, general waste and sewage disposal) $[49,50]$, for example, are subject to regulatory regimes imposed by the host nation's environmental protection authorities and planning departments [51-53]. Development applications can be rejected, and contraventions to approval conditions can be prosecuted [54]. Likewise, the impact of the operations of the resort, through the actions of their clientele, can be constrained through nature preservation regulations stipulating limits to reef access or fishing [15]. The management of other environmental parameters that are not governed by the government regulations, or that exceed the minimum requirements, such a resort's carbon footprint or its landscaping and planting with exotic species, tend to be solely framed by the resort developer's ideology and philosophy.

Social sustainability, on the other hand, is usually never legislatively mandated and, thus, subject to a resort developer's ideology and philosophy and the receptiveness of the community owning the land and/or living in the surrounding area. Here, the nature of the land tenure comes to the fore. Where the resort's land is leased, the resort developer will be required to negotiate with the local community or communities that holds land and/or usufruct rights of the resort lands and, thus, can, at least theoretically, exert some level of control over the development $[55,56]$. The extent of that control depends on the nature of land tenure (feudal, communal), the nature of the rights to the land and its resources (usufruct right, rights to marine resources) and the nature of the community (unified, fractious, polarized) [56-58]. In addition to direct payments, lease conditions for resorts can include community development aspects such as direct employment in the resort, employment as suppliers of goods and services (e.g., tours) and community infrastructure development (i.e., sharing fresh water supply and wastewater disposal systems [59]. While there are examples of demonstrable community benefits [60], there are also numerous instances of low benefit [34] and even potentially detrimental outcomes [61] such as 
cultural change [62] and disruption of both the immediate host community $[63,64]$ and further afield. For example, while communities can act as suppliers of produce to a resort and thus generate income $[65,66]$, and while traditional foods can value-add to the tourist experience $[67,68]$, the required quantities, as well as demands for specific types of foods, will cascade down the supply chain, eventually altering planting preferences [69]. Similarly, the provision of labour to the resorts will have cascading effects through the community.

A different situation can develop, where the resort's land is freehold and thus not subject to community obligations. In this case, the resort developer's ideology and philosophy are the sole modulators of social sustainability unless externalities come into effect, such as labour laws, for example, which may prescribe the nature of staff a resort can employ.

Building on King's work, this paper will focus on the intersect between sustainable tourism and heritage tourism in a resort setting. During the 1990s and early 2000s, the Yasawa and Mamanuca Islands off the north-western shore of Fiji's main island, Viti Levu, developed into an eco-tourism destination [1,5,70-72]. The question arises to what extent resort development and resort offerings in Fiji actually took up the opportunity to capitalize on the diversification offered by heritage sites and how they managed any heritage places encountered on their lands. Rather than carrying out a quantitative and qualitative of the resort industry in Fiji, this paper will focus on a single island, Malolo Lailai. Located off the north-western tip of Vitu Levu, Malolo Lailai is the home of three resorts, which target different markets and clientele, as well as a residential (retirement) community.

In the following, we will examine the historic background to the island, highlighting the largely unseen, but not invisible, cultural and historical heritage sites that exist on the island and place these into the context of the development of this tourism destination and subsequent actual resort management actions. The resort development as interpreted on the island forms part of a colonial settler narrative extinguishing past histories in favour of a post-occupation narrative. Using Malolo Lailai as a case study, the paper is a deliberation and reflection on actual tourism resort development and associated narratives, and on the opportunities of inclusion of heritage and culture narrative into future resort development and more broadly to sustainable development.

\section{The Location}

Malolo Lailai is a $2.4 \mathrm{~km}^{2}$ island located in the Malolo Group northwest of Fiji's main island, Viti Levu (Figure 1). It is separated by a narrow and shallow passage from the larger Malolo Island to the north. Topographically, Malolo Lailai is defined by low ridges in the southwest and northeast that rise a maximum elevation $55 \mathrm{~m}$ [73]. These ridges, which are comprised of exposed volcanic rocks and tephra-derived soils, are joined by an expanse of sandy soils of $1 \mathrm{~m}$ to $2 \mathrm{~m}$ above MSL (Figure 2).

Malolo Lailai is freehold land, which has been developed into a resort island complex with three distinct resorts (Musket Cove, Plantation Island and Lomani) along the northern shore. The southern and eastern shore on the island currently remains largely undeveloped but shows evidence of prior land management in the form of remnant coconut plantations (Figure 3). 


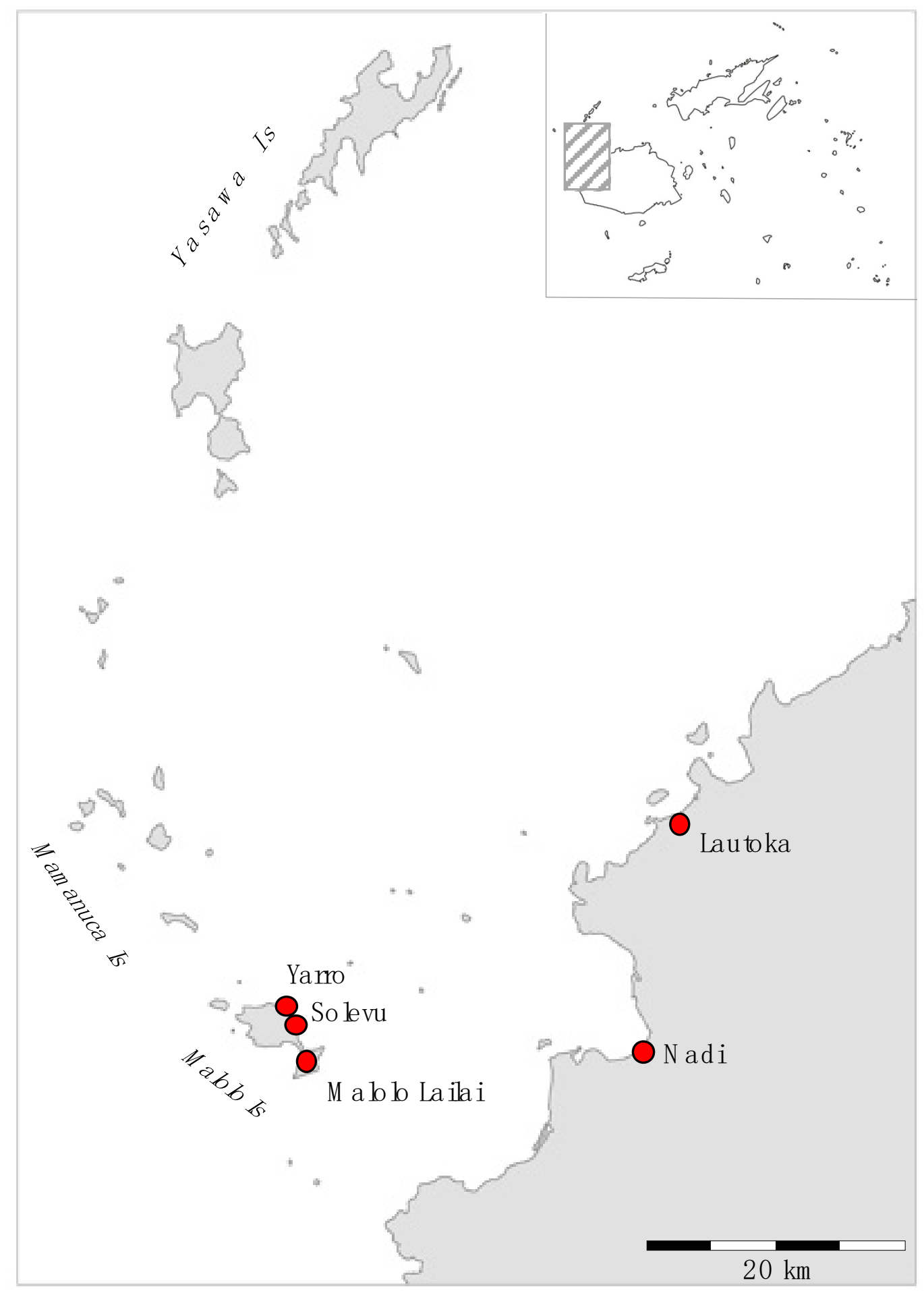

Figure 1. Overview map showing the locations mentioned in the text.

During a recreational stay on Malolo Lailai island (Mamanuca Group, Fiji) in January 2018, the author was made aware of the presence of a Chinese cemetery, which was marked on a promotional map provided by a bicycle rental outlet [74]. Upon enquiry, the resort administration could not provide any additional detail beyond the fact that the graves belonged to Chinese who had held the previous lease. On occasion of a visit to the site, it was noted that some of the graves had been dug into a mound, on the surface of which a number of subfossil shells as well as some fragments of pottery were exposed. Cursory observations at the edge of the adjacent pond showed an exposed midden with a range of 
shell species. As far as can be ascertained, no prior heritage-related and tourism-related work has been carried out on the island of Malolo Lailai, with the exception of a cursory examination by Dawson [75]. A return visit vacation in November 2019 provided an opportunity to examine the issues in more detail.

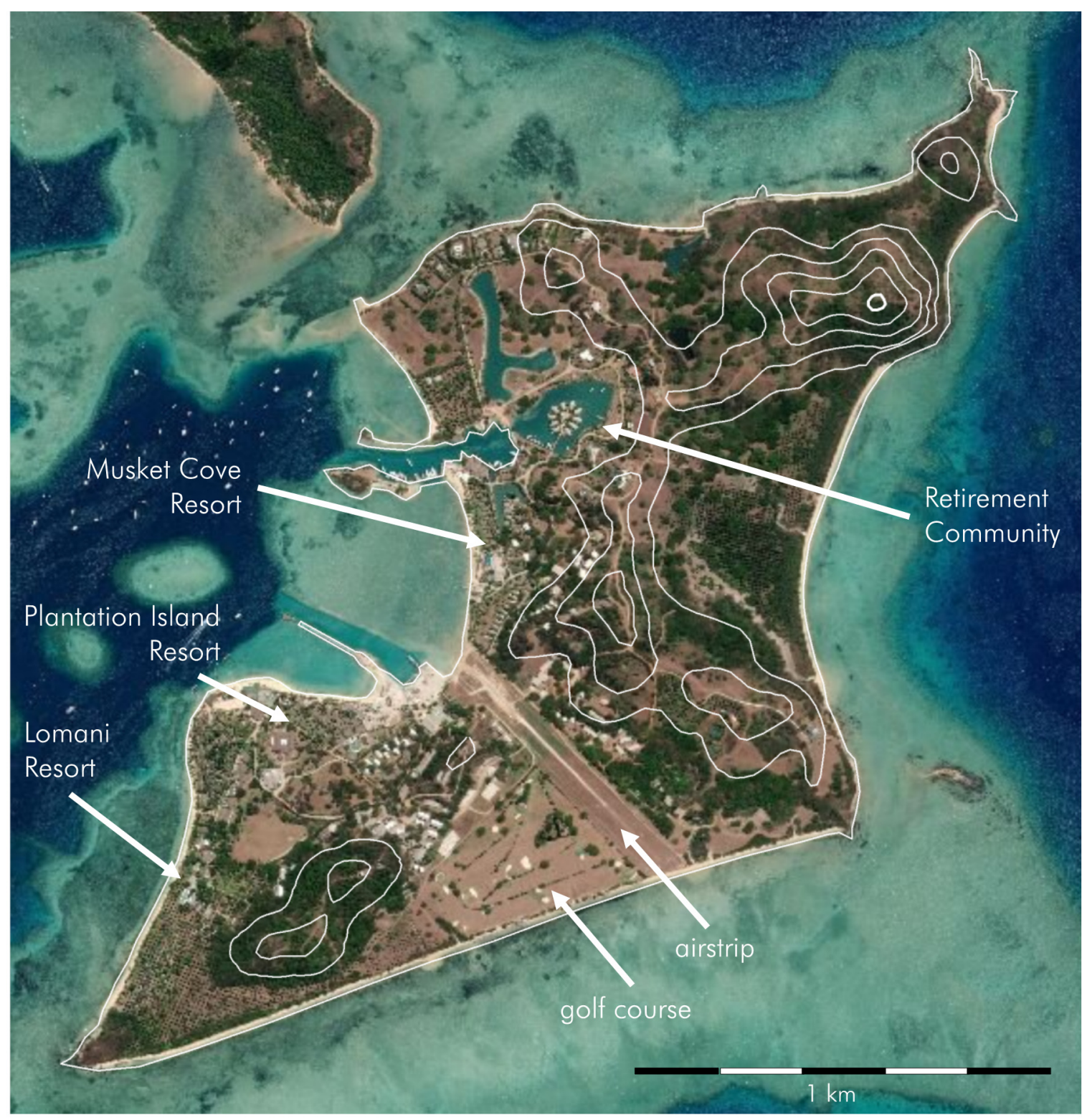

Figure 2. Aerial photograph of Malolo Lailai Island showing resort locations discussed in the text. Aerial photograph DigitalGlobe, $10 \mathrm{~m}$ contour data Directorate of Overseas Surveys [76]. 


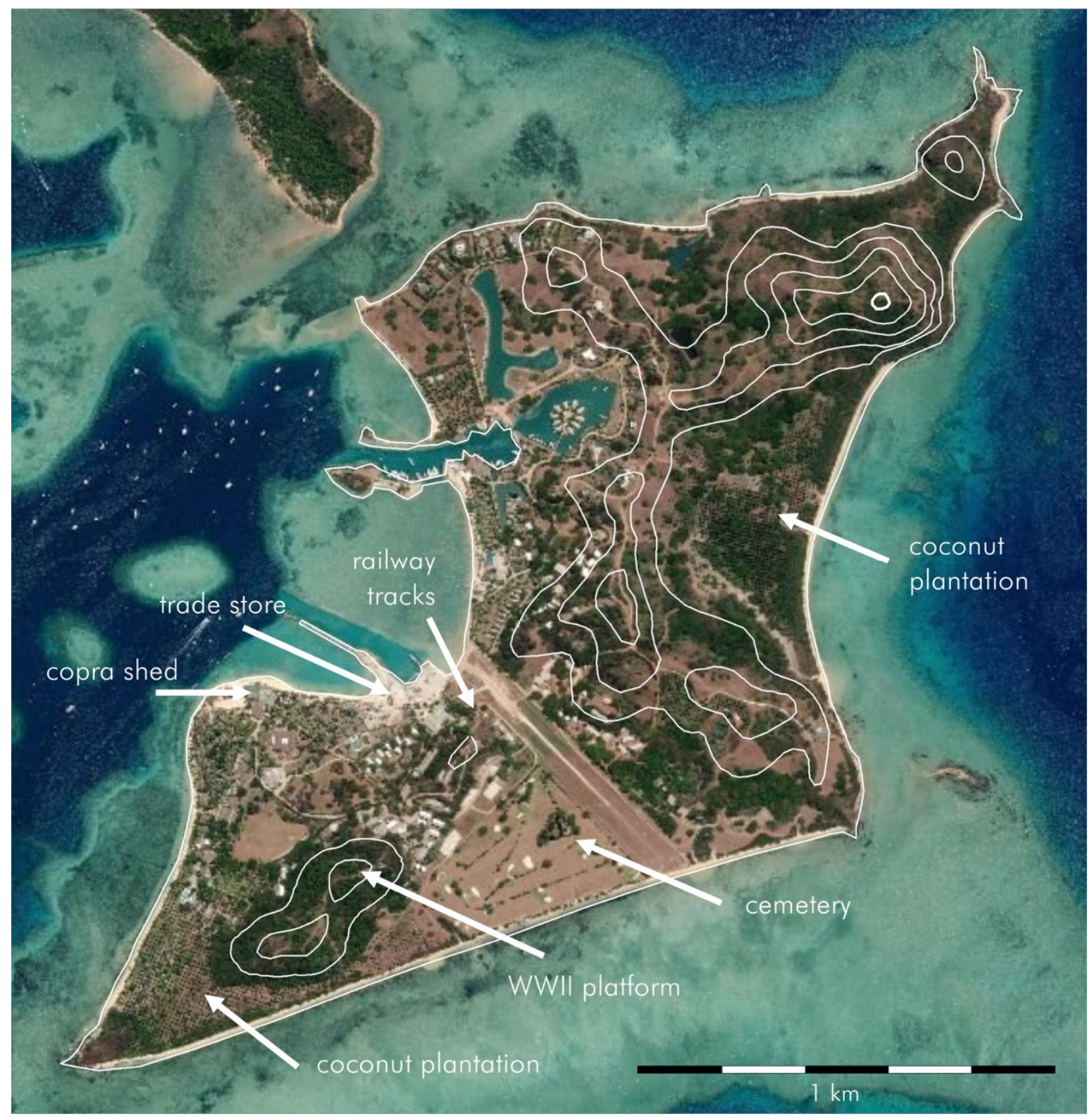

Figure 3. Aerial photograph of Malolo Lailai Island showing heritage locations discussed in the text. Aerial photograph DigitalGlobe, $10 \mathrm{~m}$ contour data Directorate of Overseas Surveys [76].

\section{Historic Context}

Even though Malolo Lailai is a major tourist destination with three resorts, very little has been researched and published on the island's history. What can be found in tourist guides is limited to unsourced data in promotional materials, e.g., $[77,78]$ and is often marred with erroneous information, e.g., [79,80]. The resort literature claims that the Nadroga chief Ratu Kini sold Malolo Lailai in 1872 to a John Thomson who wished to establish a cotton plantation. Following Thomson's death in 1876, the island was reputedly sold to Louis Armstrong, who soon after became insolvent, with the mortgagee, the Mortgage Agency of Australasia Ltd., resuming possession.

The asset was offloaded in November 1891 to the prominent planter James Borron, who then leased the island to the "Wongket family" for a period of 70 years to develop a copra plantation. In the late 1960s Richard Smith, Reg Raffe and Ian MacFarlane acquired the freehold after the Chinese lessors allowed the lease to be cut short. Initially renamed "Leeward Island", three resorts were developed on the island: Plantation Island in 1969, 
Musket Cove in 1976 and Lomani in 2004 [77,78,81]. As will become clear, this is both incomplete and inaccurate.

\subsection{Fijian History}

Little is on record about the traditional history of the Mamanuca Islands before European visitation [82]. During the mid-19th century, the Malolo Islands were under the control of the Nadroga chiefs. When the United States Exploring Expedition under Cmdr Charles Wilkes visited Fiji in 1840, two villages existed on Malolo Levu: Solevu (Wilkes: "Sualib") on the southern coast and Yaro (Wilkes: "Arro") on the north-eastern coast. Malolo Lailai, itself, was uninhabited.

\subsection{Early European Presence}

The coastline of Malolo Lailai was mapped by the United States Exploring Expedition on 22 July 1840 [83]. A cultural misunderstanding of both protocol and risk lead to the death of two U.S. officers on Malolo Levu [83]. Wilkes exacted fierce retribution by burning the two villages on Malolo, by destroying all plantations and canoes, leaving in its wake 57 dead Fijians, including two leading chiefs [84]. Using his personal connections with Ratu Kini, the paramount chief of Nadroga, John Thompson of Nadroga purchased Malolo Lailai in 1872 as freehold land, with the aim of establishing a cotton plantation [84]. It seems to have been worked by an overseer until Thompson's death in 1876. The island was then bought the Levuka hotelkeeper Louis Armstrong. Following the latter's bankruptcy in 1879, the island was managed by the Mortgage and Agency Company of Australasia until that company's insolvency in 1890. Malolo Lailai was then acquired by James Borron, a major player in Fiji's plantation industry [84]. It is unclear what, if any, plantation business Thompson, Armstrong, the Mortgage Agency of Australasia and Borron actually carried out on Malolo Lailai. Irrespective, it can be surmised that a conversion of the island into a viable plantation of any description would have entailed considerable investment in labour and that any plantations would have been on the flat ground now built on by the resort development.

\subsection{Chinese Lease Hold}

Borron may have begun to develop Malolo Lailai into a copra plantation, or he may just held the island for future use. According to Osborn [85], the Chinese Wong Ket, storekeeper in Lautoka, leased the island from Borron in 1903 for the duration of 70 years. Assuming that at the time no sizeable copra plantations existed on the island, Wong Ket's lease was a long-term investment, as the first crop would not have been ready for harvesting for five to eight years after planting [86], and peak production would only commence after ca. 15 years. Wong Ket must have engaged in an aggressive development because by 1921 his Chinese workers had reputedly planted "some 30,000 coconuts", which were all free of coconut scale [87]. Based on an analysis of available census data, it appears that the Chinese workers' presence on the island was seasonal and ranged between 10 and 20 individuals [88].

Today, there are two residual sections of that plantation laid out in a gridded fashion, one in the northeast and one in the southwest of the island (Figure 3). Much of the previously planted land has undergone clearing for resort construction as well as for the development of the airport/runway and the golf course. Looking at the topography of the Malolo Lailai (Figure 3), the total available area suitable for coconut planting is approximately 124 hectares, which equates to a total of 13,500 palms based on an estimated density of 109 palms/hectare with a spacing of six Chinese paces (步, bù). It is highly likely that the 1921 inspection team misheard the Chinese overseer's stated quantity of "some thirteen thousand" and noted it down as "some thirty thousand". The Wong family seems to have run the Malolo plantation over several generations as an ancillary income source business as it continued to operate its Lautoka business [89,90]. They allowed the lease to be bought out in 1966 when the copra market collapsed. When the lease was cut short, all 
Chinese workers had to leave on short notice. Some 700 bags of copra apparently remained on the island on the day of settlement and were sold by the new owners [90].

Residual elements of the Chinese heritage on Malolo are remnant sections of the copra plantations in the southwest and northeast of the island, the copra shed (now part of the dining area of the Plantation Island Resort) and the Chinese cemetery (Figure 3). The latter is the only known purely Chinese plantation cemetery in the Pacific Islands.

\subsection{World War II Period}

During World War II, Fiji was first provided with defences against an anticipated Japanese invasion and later developed into an Allied forward base. A number of sites are associated with this period [91], including the development of an observation station on Malolo. A concrete pad serving as an aircraft spotter platform exists on Malolo Lailai [92].

\subsection{Resort Development}

In early 1966, the Australian Richard Smith, who had already developed nearby Castaway Island [93], Reginald Raffe and Ian MacFarlane (founder of Southern Pacific Petroleum) acquired the freehold after the Chinese lessors allowed their lease to be cut short [94] - a decision that was partially motivated by the slump in copra prices at that time and an associate trading recession in Fiji $[95,96]$. At the same time, tourism was seen "as a means of economic salvation" [96]. The period of the late 1960s saw the beginnings of small-island resort development in Fiji, especially on islands where the acquisition of freehold land allowed for unfettered development. After acquisition, Malolo Lailai had informally been renamed "Leeward Island", a name that was dropped again once the Plantation Island resort had been opened in late $1969[77,97]$ and had begun to attract visitors. The initial market were budget travellers prepared to accept primarily genderseparated dormitory-style accommodation [72,98]. An airstrip was levelled in 1971 [99], operational by September 1972 [100] and furnished with a short section of narrow-gauge railway (for passenger and luggage transport), with rails and rolling stock purchased from the Colonial Sugar Refining (CSR) Co or its successor the Fiji Sugar Corporation [101]. During that time, until 1973 when water shortages became an issue, Malolo Lailai was apparently used for open quarantine by the Fiji Department of Agriculture [102]. Resort development accelerated with the opening of Musket Cove Resort (originally "Dick's Place") in October 1976 [80,103] and Lomani Resort in 2004 [78]. A nine-hole golf course, designed by Ananda Madhwan, was added in 1996-1997 (opened 12 July 1997 plaque in coral boulder at golf course). In 2002, Ian MacFarlane's share was sold to the other two investors [104]. Emulating developments in the Caribbean, in 2005, parts of Musket Cove were sold off as a marina-type development with a lifestyle enclave of private residences [105].

The resort developments focused on the northern shoreline with predominately villastyle accommodation set in a network of pathways, augmented by peripherally sited support infrastructure and workers accommodations. Buildings and infrastructure were continually redeveloped and upgraded. By 2020, the three resorts had a combined total of 250 rooms (Plantation Island, 165 rooms, ca. 600 guests; Musket Cove, 55 rooms, ca. 195 guests; Lomani 30 rooms, 60 guests) [77,78,103], with an annual volume of over 100,000 guests (the company-owned ferries annually transport 120,000 passengers (including resort staff and day visitors) [106].

\section{Tangible Heritage Evidence}

The site, located in the southern part of the island (Figure 3), is a palimpsest comprised of multiple layers of occupation and land modification (not in chronological order): a pond, a cemetery, a Fijian village (midden) site and a golf course. These elements shall be discussed in turn. 


\subsection{Chinese Pond and Cemetery}

The pond is an artificial depression penetrating the groundwater lens (Figure 4). The bottom depth varies from approximately $1 \mathrm{~m}$ in the northwest to $\geq 2 \mathrm{~m}$ in a L-shaped channel along the southern and eastern margins. The excavated spoil was heaped into the soil mound into which some of the burials were dug. During the resort period, the pond was widened, with some the spoil distributed across the golf course to form undulations and small (now vegetated) mounds delineating the fairways.

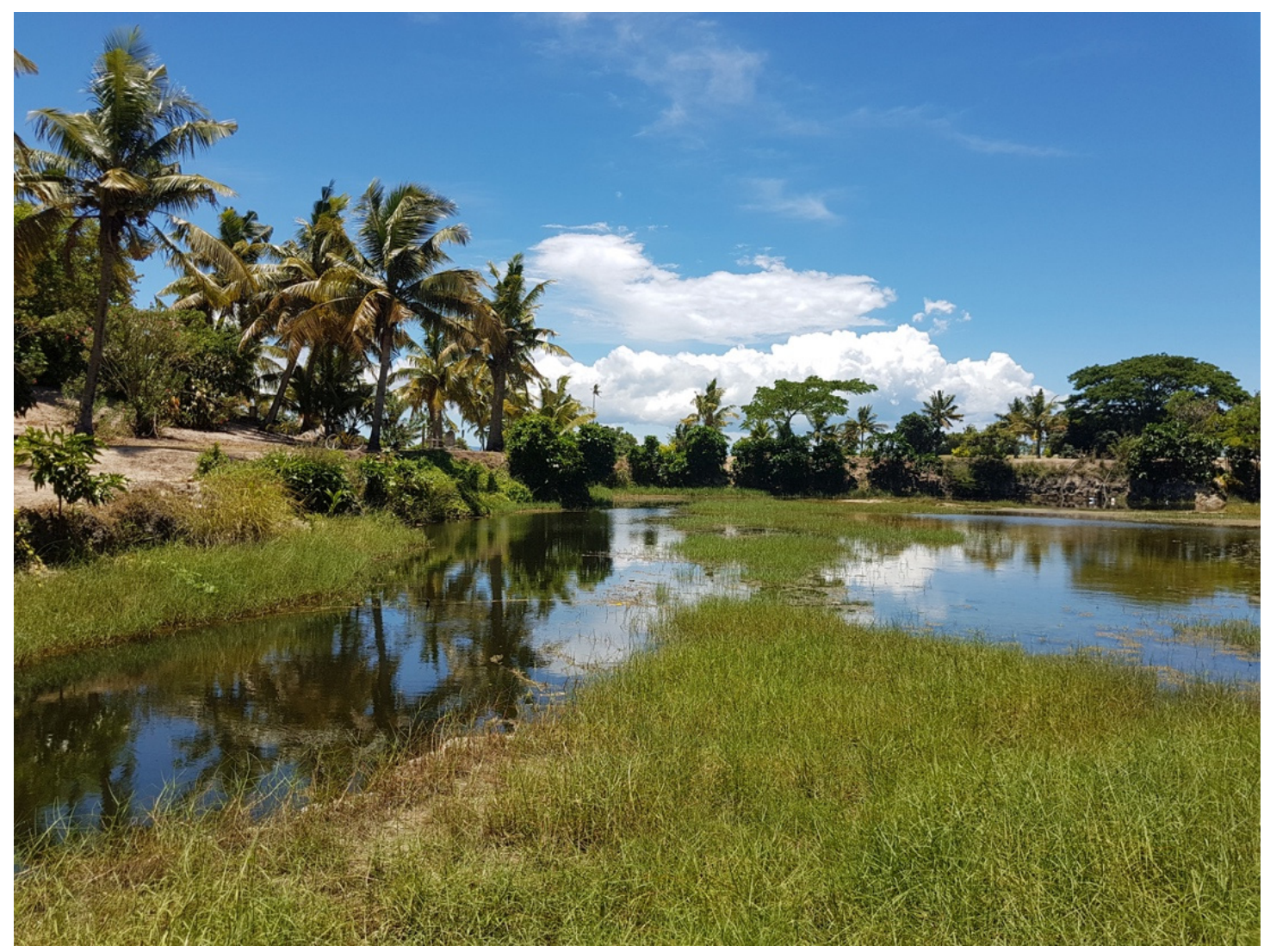

Figure 4. The pond, looking south. The soil mound is to the left of the image. The midden deposits are exposed along the entire profile.

The cemetery is located at the southern side of the soil mound. As the cemetery has been discussed elsewhere in detail [88], a brief summary can suffice. The first row of burials is interred in the northern face of a $1.5 \mathrm{~m}$ (north) to $2 \mathrm{~m}$ (south) high soil mound, which measures about $13 \mathrm{~m}$ in width (east-west) and $19 \mathrm{~m}$ in length (north-south) (Figure 5). The second row, which is set about $8 \mathrm{~m}$ to the south, is interred on flat ground. The graves are marked with concrete foot stones as well as grave surrounds marked off with coral boulders (Figure 6). The last grave to be dug (1951) is lined with a concrete fence-line surround. Seven of the eight grave markers carry fully or partially legible inscriptions (Figure 6). Six of the identifiable burials, with identifiable dates from 1914 to 1929, belong to members of the Huáng (Wong) family who worked the plantation. At least five of the interred men stem from Zhōngshān (山中) in the Pearl River Delta of Guăngdōng Province, Canton [88]. One burial belongs to Guān Yùshèng Jūn, who operated a trade store on the island until his death in 1951 [90]. 


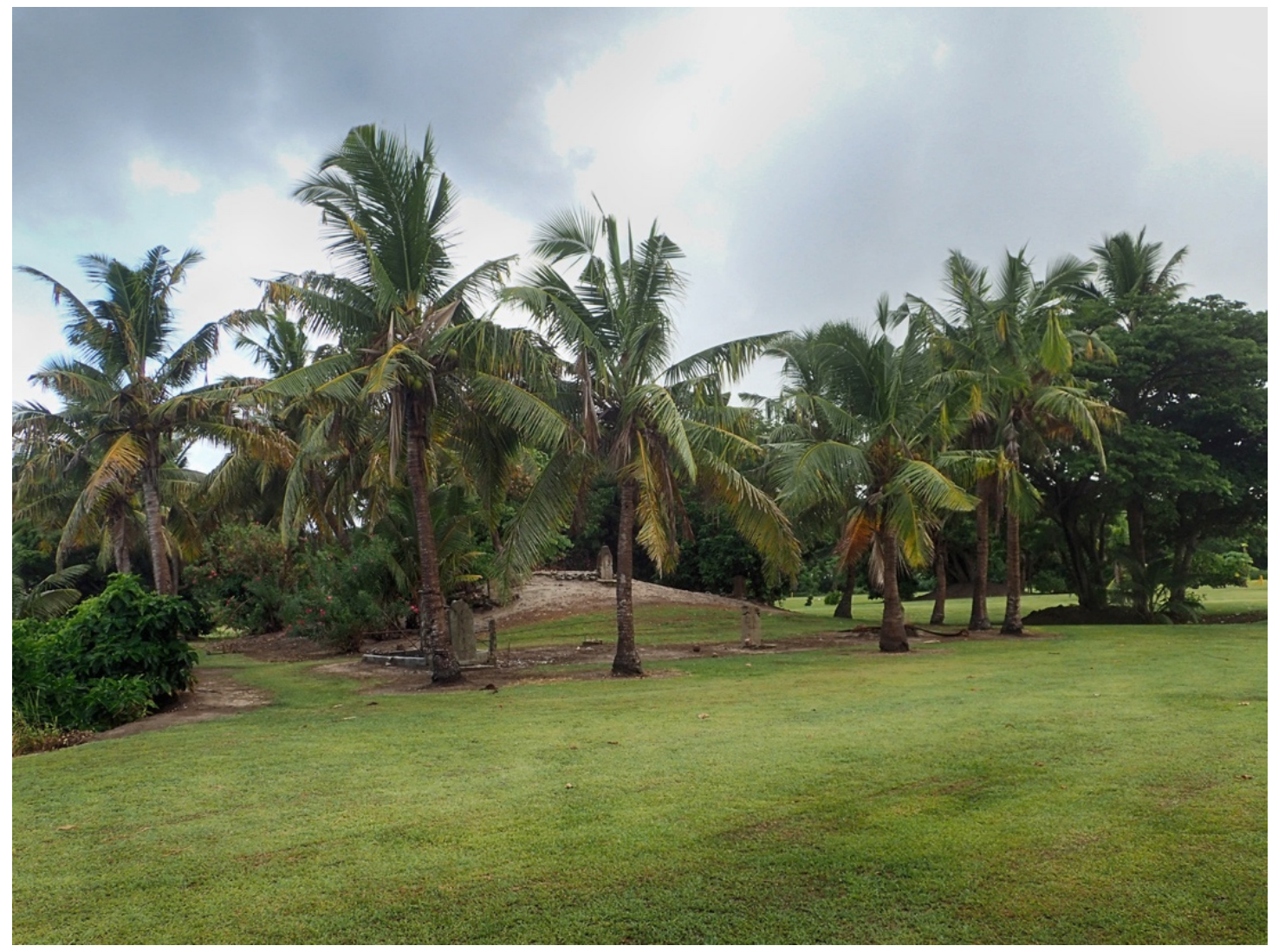

Figure 5. The mound and Chinese cemetery at the edge of the fairway of hole $n^{\circ} 7$, as seen from the southwest.
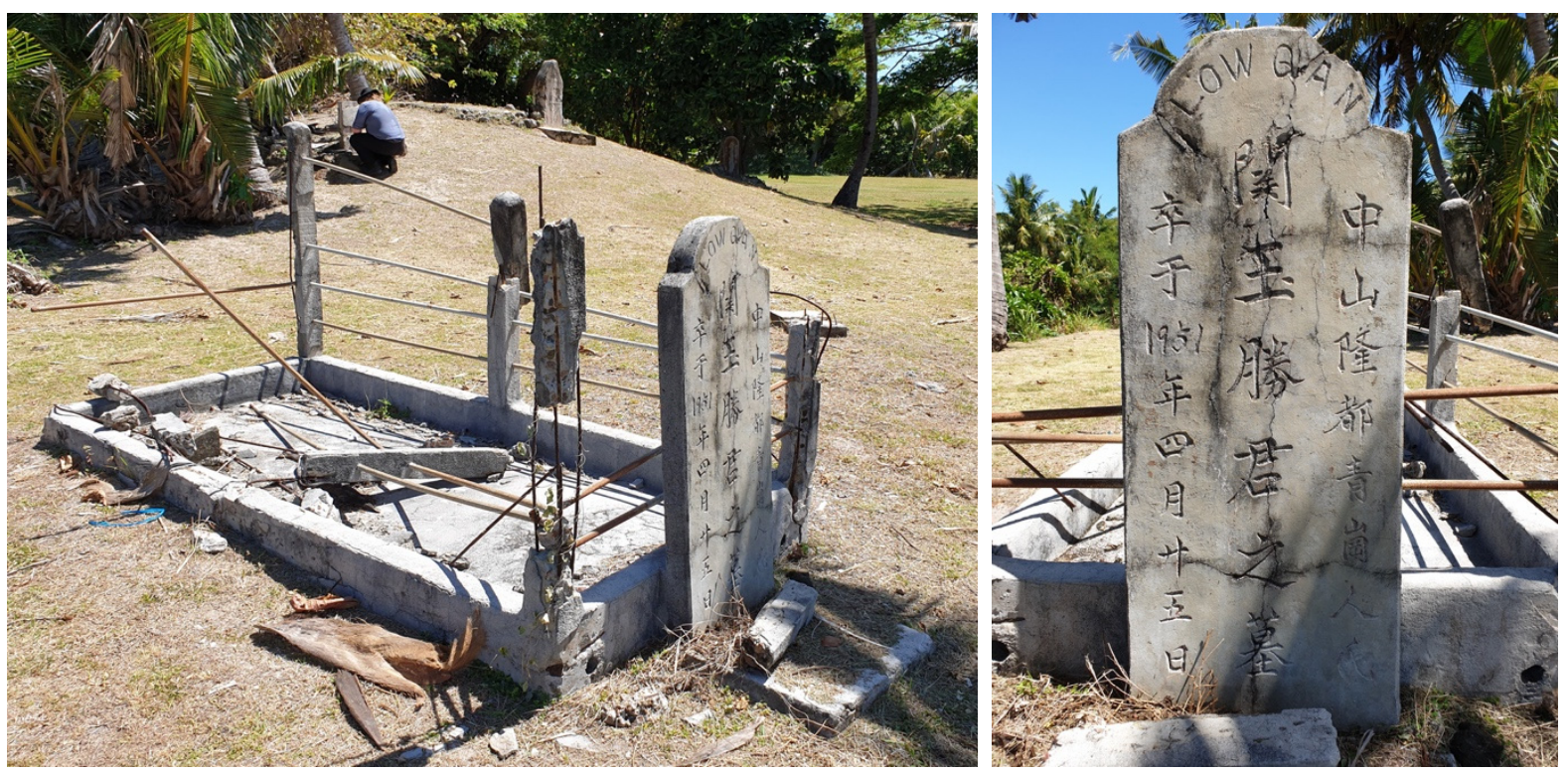

Figure 6. Concrete foot stone and surround of the grave of Guān Yu Sheng Jun, the last Chinese to be buried on the island.

\subsection{Indigenous Fijian Sites}

Cursory, unsystematic observations of the midden site and surrounds noted primarily undiagnostic pieces of ceramics as well as midden material exposed in the cut edges of the pond; on the surface of the mound into which the burials had been dug; at various planting beds on the adjacent golf course, as well as in spoil excavated from a culvert near 
the western margin of the runway; and at an exposure along the beach at the southern end of the runway. In view of the pottery composition, the midden most likely dates to the Vuda phase (1000-1800 CE) of Fijian history, most likely after 1500 [107].

A number of human bones were reputedly encountered when the end of the fairway and the green for hole $\mathrm{n}^{\circ} 4$ were shaped during the development of the golf course in late 1996 or early 1997. As the Lautoka police determined the bones to be (pre-)historic, they were collected and reburied in the same small hill as the Chinese graves. Apparently, no archaeological or heritage investigation or assessment was undertaken at the time [90].

\subsection{Site Genesis}

Based on these observations, the genesis of the Malolo Lailai site occurred in the following phases. An unfortified village was established on the sandy ground between the small hills in the northeast and southwest of Malolo Lailai during the Vuda Phase of Fijian history (1000-1800 CE). It can be surmised that the hills with their cover of volcanic ash-derived soils would have been used for gardens and plantations. The village site had been abandoned well before Wilkes' visit, as no indications of a village or its remains were noted in 1840. During the early period of Chinese plantation development, a well was dug to expose the groundwater lens. The soil from that excavation, which contained midden material from the village site, was piled into a spoil heap on the southern side. The village site was further impacted by the levelling of the runway to the northeast, and then further reshaped by the fairway partitions and bunker developments for the golf course. The required soil for these developments was sourced by enlarging the L-shaped well into a triangular pond, thereby creating an additional water hazard.

\section{Discussion}

As King has shown, many of the resort developments have the opportunity to valueadd to the tourism experience by drawing on archaeological and cultural sites on the island they are located on [9]. Moreover, the inclusion of community culture and heritage in the tourism product are deemed essential ingredients of eco- and sustainable tourism, with awareness of potentially detrimental social impacts on the host communities. In most instances, tourism and resort development occurs of land leased from local communities with land use caveats, retention of some usufruct and marine resource rights and local employment levels, as well as the supply of local community-sourced goods and services stipulated in many lease agreements. While the local community can act as custodians and advocates of the heritage sites within a resort based on lease hold land, heritage custodianship is based on social relevance to the present generation [108]. Thus, the local community may attribute different values to places of their own cultural past as opposed to that of the colonial powers [109,110], while tourists may project different values [111]. The development and operation of sustainable tourism resorts is perpetually caught in the tension between the needs to develop and offer a sustainably profitable product that, at the same time, remains socially and environmentally sustainable irrespective of changes in service expectations by the tourist clientele and delivery expectations by the host community.

There are, however, occasions where the entire resort space, bounded by ocean, is privately owned as freehold land and where any relationships with the local community are limited to shared marine resources. Such scenarios provide both opportunities for comprehensive overall resort planning that can include an island's culture heritage sites within the resort property as part of a value added the tourism experience but that can also lead to intentional neglect and even abuse. Malolo Lailai is such a case.

From a resort management perspective, Malolo Lailai differs significantly from other resort developments in Fiji, as the island is one of the few places which "had been bona fide bought by or given to Europeans and other foreigners prior to cession [in October 1874]" [112]. Moreover, it is an island that it owned in its entirety. By virtue of being bounded by water, Malolo Lailai not only shares no land boundary with neighbours who might have potentially competing land use interests, it also confines the movements of 
guests. This provides the owners with freedom to develop the island on a long-term business trajectory with a cohesive and comprehensive resort development plan.

\subsection{The Extinguishment of Past Histories in Favor of Twentieth-Century Settler Narrative}

At least in theory, the owners had the ability to develop an inclusive tourism experience that extends beyond the sun, sea and sand experience and more along the lines suggested by King [9]. Clearly, that opportunity has not been taken up so far. All physical development followed the three " $\mathrm{S}$ " dictum, with the more recently added element of a retirement community (Figure 1). In fact, none of the environmental features are interpreted in any shape or form, nor is any pre-resort development, heritage which seems to be studiously ignored. The "library" of Plantation Island Resort carries a number of fish and shell identification books but does not have any information on the island's cultural or environmental history, even though this is not that difficult to compile [84,88]. The provision of historic context of the pre-resort period as provided by the three resorts is limited to references in the resort "literature", i.e., the promotional materials, e.g., [77,78,103], which are not only cursory but also factually incomplete. Of concern is that that modern media marketing, as well as websites and Facebook posts by visitors, pick up any easily accessible material and uncritically perpetuate the myth $[113,114]$ and very often verbatim plagiarize the text provided by the resort [115].

Apart from the minimal reference to the Chinese copra lease in the resort "compendia", there are no other references, let alone interpretative material, related to the plantation operations. The main dining area at Plantation Island resort is called the "Ole Copra Shed", but there is no contextualization or explanation. From the perspective of a visitor staying at the resort, the island (apart from the obvious resort developments) appears to be a virgin, natural space disembodied from history. In the perception of most tourists, tropical islands are anyhow studded with coconuts, and, thus, coconut palms growing in the interior do not trigger any understanding of prior land use.

With the passage of time and the loss of eyewitnesses to the resorts' development, historic "realities" prove to be fluid. Consequently, the physical heritage of the Malolo Lailai is subject to re- and misinterpretation. A good example is the short section of narrowgauge railway track that was laid in conjunction with development the airstrip was levelled in 1971 [99,101]. As the railway fell into disuse, the remaining tracks, which can be found protruding along a path parallel to the runway (Figure 7), have now been conjecturally reinterpreted as remnants of a former copra train [116].

A map of the island provided by the bicycle rental agency Bula Bikes [74], labelled a number of primarily natural points of interest without further explanation, including the "Chinese Cemetary [sic]". The A4-sized, single-paged map, still distributed in January 2018, was no longer available in November 2019. The orientational signboards displayed in the resorts are limited to the layout of the main resort accommodation and do not encompass the cemetery or other parts of the island. The cemetery is also not mentioned in any of the resort "compendia".

The Musket Cove Guide, which is the most detailed, contains limited text on Fijian culture but makes no reference to the island's sites [103], Likewise, the overwhelming majority of photographs and other images decorating the walls of the "Trader's Café" at Musket Cove are generic Fijian imagery with little if any relevance to Malolo Lailai. Yet, the Trader's Café has on display a number of objects, such a Morgan TF sportscar and an array of suitcases, all being Dick Smith's erstwhile property. Some of these items are displayed behind glass in a museum-like setting, which, coupled with photographs of Richard Smith († 2012) in his Australian days, manifest the personal aggrandizement and heroicisation of Smith and essentially represent a founder's mythology for Musket Cove and its permanent retiree population. Essentially, the "real" history on the island began in 1966. 


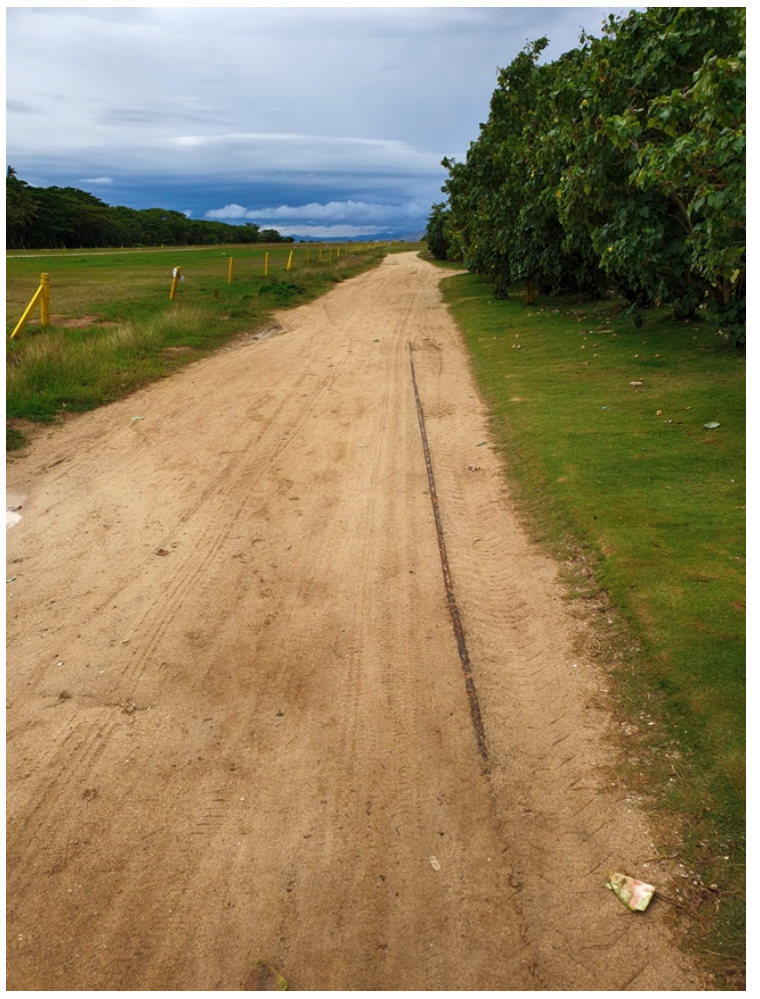

(a)

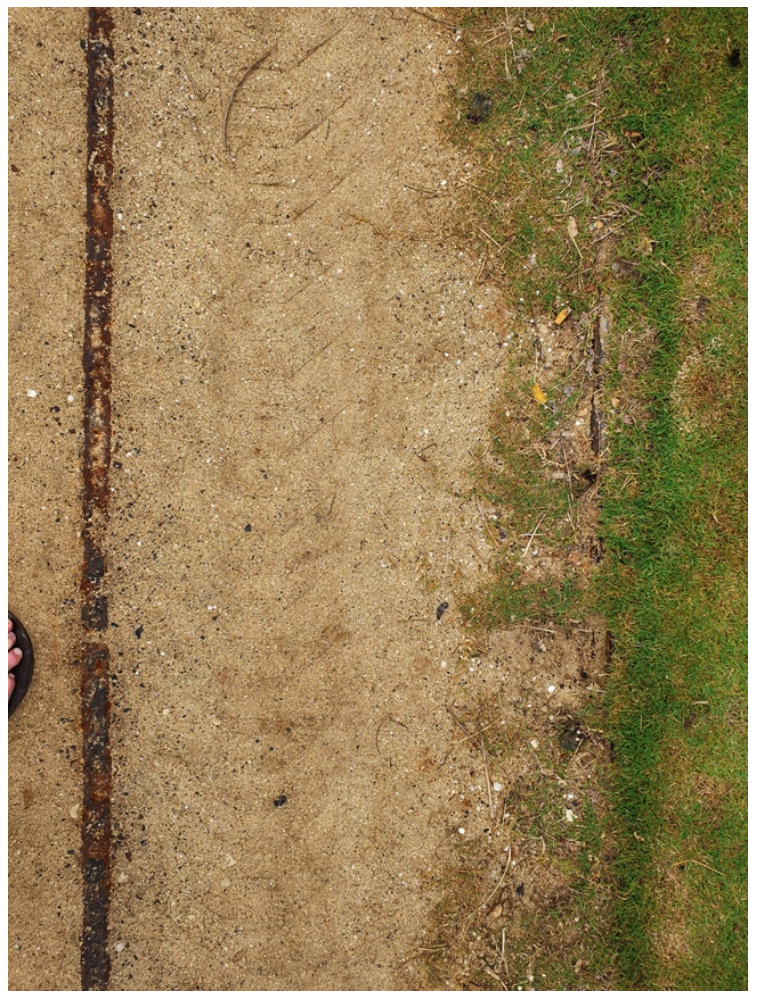

(b)

Figure 7. Section of narrow gauge railway track. (a) track exposed on path parallel to runway; (b) detail.

This mythology of carving a resort out of nothingness dovetails with the "heroic" status of Smith and Raffe as pioneers of the resort tourism industry in Fiji during the terminal years of British colonial rule (until 1970) [116-119]. It extinguishes past histories in favour of a post-occupation, twentieth-century colonial settler narrative. As such, it strongly echoes how primarily Anglo-Celtic settler societies in Australia and North America constructed their identity [120,121], as well as a euro-centric bipartite history, divided into a before and an after arrival period, with the former part either totally ignored or heavily devalued. This is a narrative where the heritage sites of the "before" are merely allowed to co-exist-provided they do not impact resort development objectives. It can be posited that the original resort developers were, consciously or subconsciously, imbued with a similar settler mentality and that, in the absence of any social controls and external influences, this narrative was allowed to be consolidated.

The author's second stay coincided with the celebrations of the 50th anniversary of the resort development. Setting aside some comments made online via the resort's webpage [122], which repeats the minimalist the detail in the brochures, none of the publicity material made available on island, on public notices or announcements made any reference, let alone provided an acknowledgement of the pre-resort history or heritage of the island. The anniversary celebrations reinforced this now dominant narrative, which has been embraced by the retirement community that is developing on the island.

\subsection{A Developer's Moral Compass and the Autonomy Derived from Unfettered Ownership}

The point was made earlier that, while the environmental sustainability of the resort development is subject to legal standards imposed by the host nation's environmental protection authorities and planning departments, all parameters which are not governed by these, or that exceed the minimum requirements, are framed solely by the resort developer's philosophy. The fact that Malolo Lailai has been freehold title since 1872 [84] meant that the island's owners could develop their resorts without the need for any traditional approval 
but also without the need for any external consultation and input, whatsoever. This is in contrast to neighbouring resort developments [123].

The autonomy to develop is derived from unfettered ownership and reinforced by legislative practice. While planning regulations and environmental standards are not static but are subject to political and administrative change $[4,124,125]$, most legislation is not retrospective. Consequently, while breaches after the promulgation of the legislation can be prosecuted [54], developments that had occurred before relevant standards or tourism development polices had been introduced tend to remain exempt from compliance. In addition, malevolent actors can achieve environmentally detrimental development outcomes when the development is carried out incrementally and, under the guise of "maintenance", often stays below the approval threshold.

Indeed, while jurisdictionally part of the Malolo District of Nadroga-Navosa Province (Western Division), legally enforceable planning controls were absent. Moreover, until the 2005 passage of the Environmental Management Act, no development required a formal impact assessment, and even under that Act, provisions are not very strong [126] Moreover, in the absence of any formal archaeological or heritage survey, sites were not known to exist and thus escaped attention of the Fiji Museum as administrators of the Preservation of Objects of Archaeological and Palaeontological Interest Act (1940). That the three resort owners and developers had little interest in respecting, let alone preserving, Fijian heritage is evidenced by the fact that a pre-19th century Fijian cemetery was reputedly levelled to make way for the golf course development.

Avenues to exert external social pressure to comply with current standards are absent in settings where the resort is located on freehold land. Unless resort ownership is held by a larger group of private or public listed investors on whom pressure to comply can be brought to bear, a single person or small collective owners will be able to exercise unlimited autonomy derived from their unfettered ownership. Moreover, unless a deficit is blatantly obvious, the majority of a resort's clientele will remain oblivious, even though, in general, they may be favourably inclined to embrace change [1,127].

In the Fijian setting, the meanings and values attributed physical and the socio-cultural environment are closely intertwined [64,128]. Since Malolo Lailai is freehold land without a resident Indigenous Fijian community, the iTaukei Land Trust Board has no jurisdiction over the management of the island and its relations with Fijian communities [9]. Traditional Fijian culture, in the context of Plantation Island resort, is reduced to commodified presentations of kava, a repertoire of "classic" Fijian songs during dinner (e.g., "Isa Lei"), occasional dances by resort staff and some mat weaving demonstrations with audience participation (mainly children). Upon arrival, visitors are welcomed with "classic" Fijian songs and a "traditional" shell necklace. The latter is a mass product imported from the Philippines or Indonesia (Figure 8) as is the majority of the souvenirs. There appears to be no obvious input into the program from the Fijian community of the neighbouring Malolo or adjacent islands.

In the absence of a comprehensive national strategy [126], there is no national and unified approach to and guidance for cultural heritage tourism, leaving any implementation to a resort owner's individual ideology and philosophy [129].

In theory, the multi-layered heritage of Malolo Lailai affords the owners with a unique opportunity to diversify and enrich the visitor experience by value-adding the traditional triple " $\mathrm{S}$ " product with the addition of cultural and historic components. The leisure environment of the resorts would allow for a sensitive interpretation of cultural conflict, as exemplified by the events of 1840 across the bay; by the mutual opportunism displayed by Ratu Kini and John Thompson with the land transaction 1872; by the economic imperialism of James Borron capitalizing on the sell-off of the insolvent Mortgage and Agency Company of Australasia; and by the entrepreneurial ambitions of Wong Ket and, later, the three investors of the resort. 


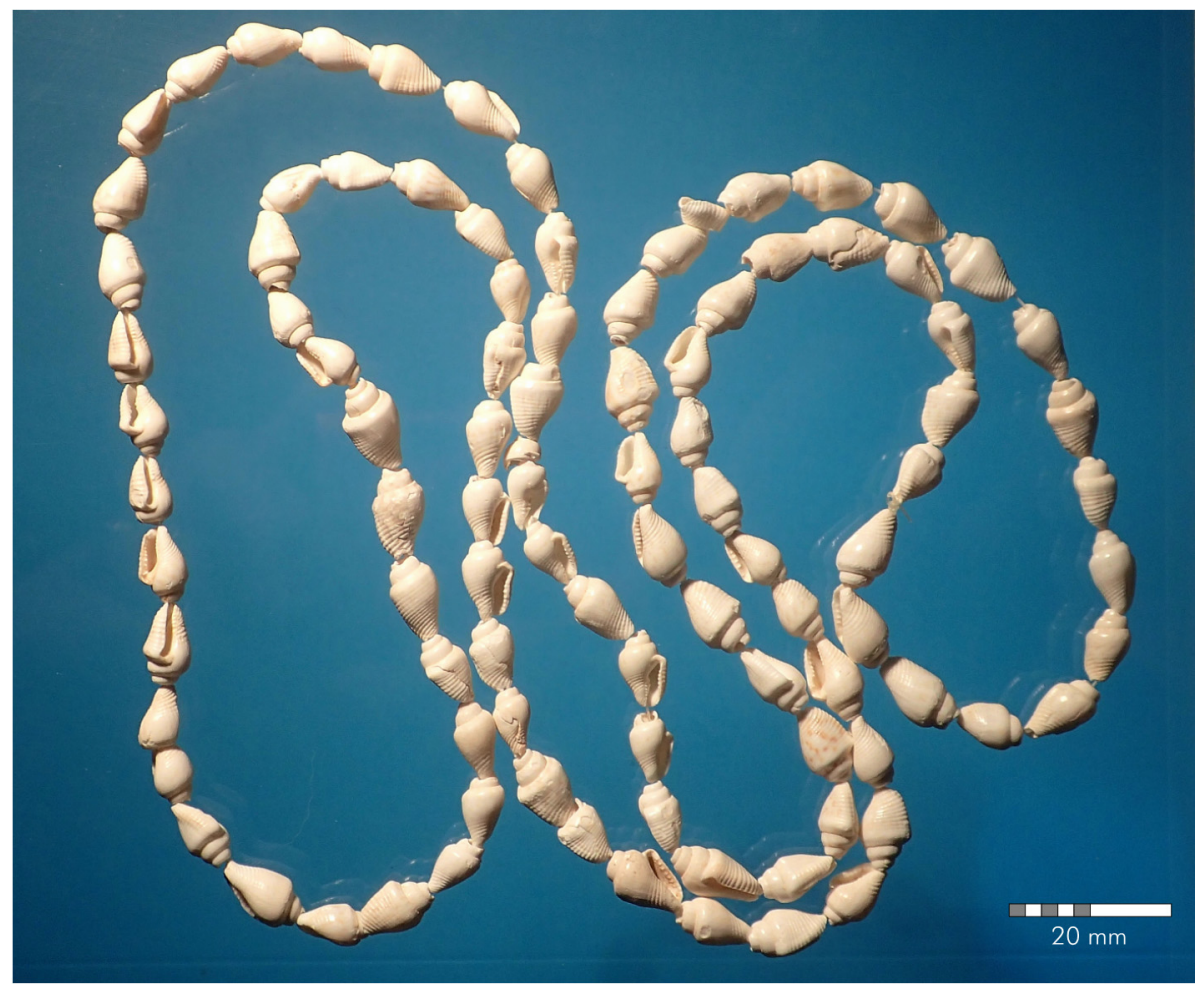

Figure 8. "Authentic" Fijian necklace ("lei") made from Nassarius sp. molluscs and imported from the Philippines or Indonesia (length $90 \mathrm{~cm}$ ).

As noted, the autonomy derived from unfettered ownership provides an opportunity for the development of a meaningful interpretation of the heritage sites on the island as a value-adding component of tourism [130], if not to a wholistic positioning of the resort in its historic and physical environment. There is a risk of the commercialization of cultural heritage and associated historical knowledge, in particular where the interpretation does not take appropriately into account the meaning and significance of cultural heritage to the originators of that heritage. Any utilization of heritage sites is always at risk of being exposed to an over-exposure by the tourist gaze by associated dangers of commodification and selective falsification [5,131-133].

Clearly, in its present state, the Fijian village midden site with its exposed pottery is not suitable for interpretation, as a loss of cultural materials is likely during subsequent visitation. One the other hand, site stabilization measures, such as simple revegetation of the perimeter of the pond's edge, would obscure the midden, thereby limiting losses to material exposed in the flower beds of the golf course.

Such considerations do not apply to the elements of plantation Chinese heritage. While it is not surprising that non-ethnic heritage tends to be sidelined in many situations of post-colonial cultural and political self-affirmation and self-determination [110], the lack of interpretive attention given towards the Chinese heritage elements requires more explanation. It appears that scant attention has been paid to the history and role of Chinese shop keepers, traders and planters [134,135] and that, throughout Fiji, no sites associated with Chinese heritage have been listed, protected or interpreted. While there is no evidence of overt racism in Fiji (unlike in Tonga) [136], the Chinese community is nonetheless marginalized. As such, then, the treatment of the Chinese heritage sites on Malolo Lailai conforms with the general "norms". The Chinese plantation heritage presents a unique opportunity to address this imbalance rather than perpetuating marginalization towards the mainly Australian and New Zealand clientele of the resort. To what extent this can be realized depends on the resort developer's moral compass. 
That compass appears very much limited, however, without much indication of change. In this context, it is worth noting that resort management deemed a recently identified plain concrete pad for a WWII era aircraft spotter position to be of heritage value worth developing into a "war memorial site" [92]. Resort management is quoted as stating that "we have a lot of Australians and New Zealanders staying with us and we can already see how such a site could hold great meaning not only for them but for our Fijian soldiers" [92]. While the site precedes the twentieth-century settler narrative mentioned above, the fact that this site is singled out for interpretation is congruent with this as it a manifestation of a euro-centric colonial heritage narrative.

\section{Conclusions}

The initial resort development of Malolo Lailai occurred during the largely unregulated pioneering days in the late 1960s and early 1970, giving free reign to unfettered concepts. As environmentally and socially sustainable tourist developments sprung up elsewhere in the Mamanucas and the nearby Yasawas, nothing has changed conceptually on Malolo Lailai, which still relies on the "tried and true" sun, sea and sand model.

Rather than drawing on the extant heritage sites as present or future assets, the sites are merely allowed to co-exist, provided as they do not impact resort development objectives. As such, the resort development is a variation of an Anglo-Celtic colonial settler narrative extinguishing past histories in favour of a post-occupation narrative.

The preceding deliberation and reflection on the resort development and associated narratives on Malolo Lailai has highlighted the pivotal role of an individual's agency in situations where a resort's land is freehold and thus not subject to community obligations and where its foundational development occurred at a time when there was a vacuum of environmental protection and planning controls. In such settings, any environmentally and socially sustainable tourism development relies on the moral compass and development philosophies of the developer. Impervious to external controls, the only avenue for direct change is through pressure by the tourist clientele or through change of ownership.

In the light of the discussion in this paper, a case can be made that future changes to environmental planning legislation that affect resort developments may want to consider provisions that allow, at the least, a reassessment of resort practices with obligations for rectification if required. The bill for a Heritage Act, submitted in 2016 and again in 2021 [137,138], only covers sites registered under the World Heritage Convention [139], and this has no transformative value. This it may be advisable to strengthen the provisions of the Environmental Management Act (2005) and, in particular, those of the Preservation of Objects of Archaeological and Palaeontological Interest Act (1940).

Funding: This research received no external funding.

Institutional Review Board Statement: Not applicable.

Informed Consent Statement: Not applicable.

Data Availability Statement: No data available.

Acknowledgments: I am indebted to Rudolf Spennemann (Canberra) for assistance on site, to Michael Wong (Malolo Lailai/Suva) for oral history information and to Liu Xiaoying (Institute for Land, Water and Society, Charles Sturt University, Albury) for the transcription and translation of the Chinese inscriptions on the footstones. Deanna Duffy (Spatial Analysis Network, Charles Sturt University) kindly produced the base maps for Figures 1-3.

Conflicts of Interest: The author declares no conflict of interest.

\section{References}

1. Murphy, S.E.; Campbell, I.; Drew, J.A. Examination of tourists' willingness to pay under different conservation scenarios; Evidence from reef manta ray snorkeling in Fiji. PLoS ONE 2018, 13, e0198279. [CrossRef]

2. Thornton, R.L. Tourism-west from Europe: The enticement of the foreign visitor. Bus. Horiz. 1969, 12, 27-34. [CrossRef]

3. Hall, C.M. Introduction to Tourism in Australia: Impacts, Planning and Development; Longman Cheshire: Melbourne, Australia, 1991. 
4. Xie, P.F.; Chandra, V.; Gu, K. Morphological changes of coastal tourism: A case study of Denarau Island, Fiji. Tour. Manag. Perspect. 2013, 5, 75-83. [CrossRef]

5. Sroypetch, S. The mutual gaze: Host and guest perceptions of socio-cultural impacts of backpacker tourism: A case study of the Yasawa Islands, Fiji. J. Mar. Isl. Cult. 2016, 5, 133-144. [CrossRef]

6. Alipour, H.; Olya, H.G.T.; Maleki, P.; Dalir, S. Behavioral responses of 3S tourism visitors: Evidence from a Mediterranean Island destination. Tour. Manag. Perspect. 2020, 33, 100624. [CrossRef]

7. Mestanza-Ramón, C.; Pranzini, E.; Anfuso, G.; Botero, C.M.; Chica-Ruiz, J.A.; Mooser, A. An attempt to characterize the "3S" (Sea, Sun, and Sand) parameters: Application to the Galapagos Islands and continental Ecuadorian beaches. Sustainability 2020, $12,3468$. [CrossRef]

8. Tisdell, C.; McKee, D.L. Tourism as an industry for the economic expansion of archipelagoes and small island states. In Economics of Tourism: Case Study and Analysis; Tisdell, C., Aislabie, C., Stanton, P., Eds.; Instutute of Industrial Economics, University of Newcastle: Newcastle, UK, 1990; pp. 181-204.

9. King, B. Creating Island Resorts; Routledge: London, UK, 2002.

10. Ministry of Tourism. Fiji's Tourism Development Plan 2007-2016; Department of Tourism, Ministry of Tourism: Suva, Fiji, 2007.

11. Butler, R.W. The concept of a tourist area cycle of evolution: Implications for management of resources. Can. Geogr. Géographe Can. 1980, 24, 5-12. [CrossRef]

12. Choy, D.J. Life cycle models for Pacific island destinations. J. Travel Res. 1992, 30, 26-31. [CrossRef]

13. McElroy, J.L. Small island tourist economies across the life cycle. Asia Pac. Viewp. 2006, 47, 61-77. [CrossRef]

14. Buckley, R. Surf tourism and sustainable development in Indo-Pacific Islands. I. The industry and the islands. J. Sustain. Tour. 2002, 10, 405-424. [CrossRef]

15. Fitzsimmons, C. Why dive? And why here?: A study of recreational diver enjoyment at a Fijian eco-tourist resort. Tour. Mar. Environ. 2008, 5, 159-173. [CrossRef]

16. Spennemann, D.H.R. Feasibility Study on Improving Tourist Attractions, Notably Historic and Archaeological Sites within the Kingdom of Tonga. Consultancy Study Prepared for the Secretariat of the Tourism Council of the South Pacific (TCSP); Draft Final Report; Secretariat of the Tourism Council of the South Pacific: Suva, Fiji, 1987.

17. Spennemann, D.H.R.; Putt, N. Cultural Interpretation of Heritage Sites in the Pacific; Pacific Islands Museums Association: Suva, Fiji, 2001.

18. Sayers, E.; Spennemann, D.H.R. The Role of Cultural Attractions in the Motivations and Awareness Spectrum of Japanese Tourists in the CNMI. Micrones. J. Humanit. Soc. Sci. 2006, 5, 373-385.

19. Sayers, E.; Spennemann, D.H.R. Provision of information on Cultural Attractions to Japanese Tourists in the CNMI. Micrones. J. Humanit. Soc. Sci. 2006, 5, 411-428.

20. Spennemann, D.H.R.; Look, D.W.; Graham, K. Heritage Ecotourism in Micronesia: What do Decision Makers expect? Pac. Tour. Rev. 2002, 6, 51-61.

21. Look, D.W.; Spennemann, D.H.R. Heritage Eco-Tourism Symposium, Rota, Feb. 28-Mar. 3, 2000. Cult. Resour. Manag. $2000,23,35$.

22. Edney, J. Diver characteristics, motivations, and attitudes: Chuuk Lagoon. Tour. Mar. Environ. 2012, 8, 7-18. [CrossRef]

23. Jeffery, B. World War II shipwrecks in Truk Lagoon: The role of interest groups. Crm. J. Herit. Steward. 2004, 1, 51-67.

24. Spennemann, D.H.R. Taroa, Maloelap Atoll. Air Marshall Islands Sunday Escape; Folded Tour Brochure; AIRMarshall Islands: Majuro, Marshall Islands, 1991.

25. Spennemann, D.H.R. Mile, Mile Atoll. Air Marshall Islands Sunday Escape; Folded Tour Brochure; AIRMarshall Islands: Majuro, Marshall Islands, 1991.

26. Lotz, D. World War II Remnants: Guam, Northern Mariana Islands: A Guide and History; Making Tracks: Dededo, GU, USA, 1994.

27. Lindemann, K.P. Desecrate 1: Operations against Palau by Carrier Task Force 58, 30 and 31 March 1944, and the Shipwrecks of World War II; Pacific Press: Belleville, BC, Canada, 1991.

28. McCormick, R.R. Marketing Cultural and Heritage Tourism: A World of Opportunity; Routledge: London, UK, 2016.

29. Park, D.; Nam, T.-J.; Shi, C.-K. Designing an immersive tour experience system for cultural tour sites. In CHI'06 Extended Abstracts on Human Factors in Computing Systems; ACM: New York, NY, USA; pp. 1193-1198.

30. Bec, A.; Moyle, B.; Timms, K.; Schaffer, V.; Skavronskaya, L.; Little, C. Management of immersive heritage tourism experiences: A conceptual model. Tour. Manag. 2019, 72, 117-120. [CrossRef]

31. Harrison, D. Levuka, Fiji: Contested heritage. Curr. Issues Tour. 2004, 7, 346-369. [CrossRef]

32. King, B. Cultural tourism and its potential for Fiji. J. Pac. Stud. 1992, 16, 74-89.

33. Smith, A. Levuka, Fiji: A case study in Pacific Islands heritage management. Archaeol. Ocean. Aust. Pac. Isl. 2006, 346-362. [CrossRef]

34. Scheyvens, R.; Russell, M. Tourism and poverty alleviation in Fiji: Comparing the impacts of small-and large-scale tourism enterprises. J. Sustain. Tour. 2012, 20, 417-436. [CrossRef]

35. Malani, M. Ecotourism in Fiji. In Linking Green Productivity to Ecotourism: Experiences in the Asia-Pacific Region; Hundloe, T., Ed.; Asian Productivity Organization: Tokyo, Japan, 2002; pp. 45-55.

36. Milne, M.J.; Gray, R. W (h) ither ecology? The triple bottom line, the global reporting initiative, and corporate sustainability reporting. J. Bus. Ethics 2013, 118, 13-29. [CrossRef]

37. Alhaddi, H. Triple bottom line and sustainability: A literature review. Bus. Manag. Stud. 2015, 1, 6-10. [CrossRef] 
38. Chok, S.; Macbeth, J.; Warren, C. Tourism as a tool for poverty alleviation: A critical analysis of 'pro-poor tourism'and implications for sustainability. Curr. Issues Tour. 2007, 10, 144-165. [CrossRef]

39. Lew, A.A. The global consciousness path to sustainable tourism: A perspective paper. Tour. Rev. 2020, 75, 69-75. [CrossRef]

40. Rasoolimanesh, S.M.; Ramakrishna, S.; Hall, C.M.; Esfandiar, K.; Seyfi, S. A systematic scoping review of sustainable tourism indicators in relation to the sustainable development goals. J. Sustain. Tour. 2020, 1-21. [CrossRef]

41. Bramwell, B.; Higham, J.; Lane, B.; Miller, G. Twenty-Five Years of Sustainable Tourism and the Journal of Sustainable Tourism: Looking Back and Moving Forward; Taylor \& Francis: Milton, UK, 2017.

42. Graci, S.; Van Vliet, L. Examining stakeholder perceptions towards sustainable tourism in an Island destination. The case of Savusavu, Fiji. Tour. Plan. Dev. 2020, 17, 62-81. [CrossRef]

43. Harrison, D.; Sawailau, S.; Malani, M. Ecotourism and Village-Based Tourism: A Policy and Strategy for Fiji; Cognizant Communication Corporation: Putnam Valley, NY, USA, 2003.

44. Cheer, J.M.; Pratt, S.; Tolkach, D.; Bailey, A.; Taumoepeau, S.; Movono, A. Tourism in Pacific island countries: A status quo round-up. Asia Pac. Policy Stud. 2018, 5, 442-461. [CrossRef]

45. Prideaux, B. Resort Destinations; Routledge: London, UK, 2009.

46. Prideaux, B. The resort development spectrum-A new approach to modeling resort development. Tour. Manag. 2000, 21, 225-240. [CrossRef]

47. Qian, J.; Shen, H.; Law, R. Research in sustainable tourism: A longitudinal study of articles between 2008 and 2017. Sustainability 2018, 10, 590. [CrossRef]

48. Mohi, W.K.; Akbar, M.F.; One, A.Y. Evaluation of Government Policy in Development of Pentadio Resort in Gorontalo. J. Ilmu Sos. Mamangan 2018, 7, 1-11. [CrossRef]

49. Mosley, L.M.; Aalbersberg, W.G. Nutrient levels in sea and river water along the 'Coral Coast'of Viti Levu, Fiji. S. Pac. J. Nat. Appl. Sci. 2003, 21, 35-40. [CrossRef]

50. Becken, S.; McLennan, C.-1. Evidence of the water-energy nexus in tourist accommodation. J. Clean. Prod. 2017, 144, 415-425. [CrossRef]

51. Lee, O.A. Coastal resort development in Malaysia: A review of policy use in the pre-construction and post-construction phase. Ocean Coast. Manag. 2010, 53, 439-446. [CrossRef]

52. Guo, Y.; Jiang, J.; Li, S. A sustainable tourism policy research review. Sustainability 2019, 11, 3187. [CrossRef]

53. Farrelly, T.; Schneider, P.; Stupples, P. Trading in waste: Integrating sustainable development goals and environmental policies in trade negotiations toward enhanced solid waste management in Pacific Islands countries and territories. Asia Pac. Viewp. 2016, 57, 27-43. [CrossRef]

54. Movono, L.; Graue, C. Chinese Resort Company Brought to Task for Environmental Damage in Fiji. Available online: https: //www.abc.net.au/news/2021-04-09/ freesoul-court-decision-on-environmental-vandalism-with-surfers/100038548 (accessed on 1 May 2021).

55. Waqaisavou, T. Tourism in Fiji: Native land owner attitude and involvement. In Proceedings of the Pacific Rim Real Estate Society Annual Conference, Adelaide, Australia, 21-24 January 2001; pp. 21-24.

56. Clarke, P.; Jupiter, S.D. Law, custom and community-based natural resource management in Kubulau District (Fiji). Environ. Conserv. 2010, 37, 98-106. [CrossRef]

57. Scheyvens, R.; Russell, M. Tourism, land tenure and poverty alleviation in Fiji. Tour. Geogr. 2012, 14, 1-25. [CrossRef]

58. Lin, H.-L. Colonial uneven development, Fijian Vanua, and modern ecotourism in Taveuni, Fiji. Pac. Asia Inq. 2012, 3, 41-57.

59. Lal, P.; Tabunakawai, M.; Singh, S.K. Economics of Rural Waste Management in the Rewa Province and Development of a Rural Solid Waste Management Policy for Fiji; South Pacific Regional Environmental Program: Apia, Samoa, 2007.

60. Kerstetter, D.; Bricker, K. Exploring Fijian's sense of place after exposure to tourism development. J. Sustain. Tour. 2009, 17, 691-708. [CrossRef]

61. Butler, R. Sustainable tourism in sensitive environments: A wolf in sheep's clothing? Sustainability 2018, 10, 1789. [CrossRef]

62. Tolkach, D.; Pratt, S. Globalisation and cultural change in Pacific Island countries: The role of tourism. Tour. Geogr. 2019, 1-26. [CrossRef]

63. Farrelly, T.A. Indigenous and democratic decision-making: Issues from community-based ecotourism in the Boumā National Heritage Park, Fiji. J. Sustain. Tour. 2011, 19, 817-835. [CrossRef]

64. Movono, A.; Dahles, H.; Becken, S. Fijian culture and the environment: A focus on the ecological and social interconnectedness of tourism development. J. Sustain. Tour. 2018, 26, 451-469. [CrossRef]

65. Pratt, S. Minimising food miles: Issues and outcomes in an ecotourism venture in Fiji. J. Sustain. Tour. 2013, 21, 1148-1165. [CrossRef]

66. Salvioni, C. How to make money by feeding the tourists: The case of Fiji. In Proceedings of the 105th EAAE Seminar 'International Marketing and International Trade of Quality Food Products', Bologna, Italy, 8-10 March 2007.

67. Berno, T. Sustainability on a plate: Linking agriculture and food in the Fiji Islands tourism industry. In Tourism and Agriculture: New Geographies of Consumption, Production and Rural Restructuring; Torres, R.M., Henshall Momsen, J., Eds.; Routledge: Abingdon, UK, 2011; pp. 87-103.

68. Scheyvens, R.; Laeis, G. Linkages between tourist resorts, local food production and the sustainable development goals. Tour. Geogr. 2019, 1-23. [CrossRef] 
69. Ross, A.; Bryceson, K.P. Traditional thinking: The impact of international aid on social structures and cultural traditions in agrifood chains in Tonga and Solomon Islands. J. Asia Pac. Econ. 2019, 24, 402-429. [CrossRef]

70. Gibson, D. Community-based tourism in Fiji: A case study of Wayalailai Ecohaven Resort, Yasawa Island Group. In Tourism in Pacific Islands; Routledge: London, UK, 2015; pp. 142-157.

71. Gibson, D. The cultural challenges faced by indigenous-owned small medium tourism enterprises (SMTEs) in Fiji: Case studies from the Yasawa Islands. J. Pac. Stud. 2012, 32, 102-126.

72. Connell, J. Competing Islands? The Mamanuca and Yasawa Islands, Fiji. In Archipelago Tourism. Policies and Practices; Baldacchino, G., Ed.; Routledge: London, UK, 2015; pp. 183-197.

73. Derrick, R.A. The Fiji Islands: A Geographical Handbook, 2nd ed.; Government Press: Suva, Fiji, 1957.

74. Bula Bikes. Malolo Lailai Island [map]. s.n.: S.l. 2017. Available online: https://www.tripadvisor.com/LocationPhotoDirectLinkg308256-d10822347-i251787942-Bula_Bikes-Malolo_Lailai_Island_Mamanuca_Islands.html (accessed on 22 May 2021).

75. Dawson, K.C.A. Malolo Island, Fiji: An Initial Coastal Archaeological Survey 1986-87; Government Press: Suva, Fiji, 1987.

76. Directorate of Overseas Surveys. Topographic Map Yasawa 1:50,000. In Series X754, 3rd ed.; Directorate of Overseas Surveys: London, UK, 1963.

77. Maharaj, N. Plantation Island Resort. Compendium. s.n.: S.l. 2017. Available online: https://www.plantationisland.com/ resources/uploads/downloads/Plantation_Island_Compendium_2017.pdf (accessed on 22 May 2021).

78. Kamanalagi, L. Lomani Island Resort. Compendium. s.n.: S.1. 2017. Available online: https://www.lomaniisland.com/resources/ uploads/download/Lomani_Island_Compendium_2017.pdf (accessed on 22 May 2021).

79. Stanley, D. Fiji, 6th ed.; Avalon Travel Publishing: Emeryville, CA, USA, 2001.

80. Stanley, D. Fiji Islands Handbook, 6th ed.; Avalon Travel Publishing: Emeryville, CA, USA, 1996.

81. Musket Cove Resort. Island History. Available online: https://www.musketcovefiji.com/about-us (accessed on 30 November 2020).

82. Cato, A.C. Malolo Island and Viseisei Village, Western Fiji. Oceania 1951, 22, 101-115. [CrossRef]

83. Wilkes, C. Narrative of the United States Exploring Expedition, during the Years 1838, 1839, 1840, 1841, 1842; Lea and Blanchard: Philadelphia, PA, USA, 1845; Volume 3.

84. Spennemann, D.H.R. Malolo Lailai Island (Viti Levu, Fiji) during the Nineteenth Century; Institute for Land, Water and Society, Charles Sturt University: Albury, NSW, Australia, 2021; p. 6.

85. Osborn, I. The Rough Guide to Fiji; Rough Guides UK: London, UK, 2008.

86. Harries, H. The evolution, dissemination and classification of Cocos nucifera L. Bot. Rev. 1978, 44, 265-319. [CrossRef]

87. Tarby, J.P. Extracts from Inspectors. Coconut scale (Aspidiotus species). Agric. Circ. (Fiji Dep. Agric.) 1921, 1, 6-7.

88. Spennemann, D.H.R. Chinese Plantation Heritage on Malolo Lailai. Mamanuca Group: Fiji. J. Chin. Overseas 2021, in press.

89. Yee, N. Catching the Wind: A Search for God; Xlibris Corporation: Bloomington, IN, USA, 2014.

90. Wong, M. Interview (conducted by Dirk HR Spennemann). Malolo Lailai, Fiji. 2019.

91. Young, A. World War II Archaeology in Fiji: Assessing the Material Record. Neb. Anthropol. 2012, $27,76-95$.

92. Nasiko, R. WWII find to be tourist attraction. Fiji Times. 28 October 2019. Available online: https:/ /www.pressreader.com/fiji/ the-fiji-times/20191028/281578062452389 (accessed on 22 May 2021).

93. Anonymous. Millions of memories at Dick's Place. Port Macquarie News, 8 November 2013.

94. Anonymous. There is a boom in resort building in travel conscious Fiji. Pac. Isl. Mthly 1966, 37, 119-122.

95. Anonymous. Carpenter sees bright future for NG tea. Canberra Times, 12 November 1966.

96. Fitzgerald, A.J. Tidying up the colonial backyard. Canberra Times, 8 June 1965.

97. Raymond, M. Cookstour, Not so wild about the natives cooking. The Bulletin. 7 November 1970; pp. 62-63. Available online: https://trove.nla.gov.au/work/236601141 (accessed on 22 May 2021).

98. Stanley, D. Finding Fiji, 6th ed.; Avalon Travel Publishing: Emeryville, CA, USA, 1985.

99. Anonymous. Big plans for Fiji Airline. Pac. Isl. Mthly 1971, 42, 32.

100. TCA. Department of Transport and Civil Aviation for the year 1972. J. Fiji Legis. Counc. 1974, 23, 51-64.

101. Dyer, P.; Hodge, P. Cane Train: The Sugar-Cane Railways of Fiji; New Zealand Railway and Locomotive Society: Wellington, Australia, 1988.

102. Tamanikaiyaroi, R.; Johnson, S. Major Sugarcane Diseases in Fiji. In Sugarcane Germplasm Conservation and Exchange Report of an International Workshop Held in Brisbane, Queensland, Australia 28-30 June 1995; Croft, B.J., Piggin, C.M., Wallis, E.S., Hogarth, D.M., Eds.; Australian Centre for International Agricultural Research: Canberra, Australia, 1996; pp. 51-54.

103. Musket Cove Resort. Musket Cove Resort. Your Island Guide. s.n.: S.l. 2017. Available online: https://cdn.galaxy.tf/uploads/ applications/documents/001/551/344/compendium.pdf (accessed on 22 May 2021).

104. Gibson, A. Investor Buys Part of Fiji Island through Auckland Agent. New Zealand Herald. 17 September 2002. Available online: https://www.nzherald.co.nz/business/investor-buys-part-of-fiji-island-through-auckland-agent/RRX4 DRUUPGEGALSHMTQFTXEPBY / (accessed on 22 May 2021).

105. Anonymous. Slice of Fijian Paradise up for Sale. New Zealand Herald. 24 August 2005. Available online: https://www.nzherald. co.nz/business/slice-of-fijian-paradise-up-for-sale/S3NRCNSXV7YCLPBW37CENRSBTM/ (accessed on 22 May 2021).

106. Sheltrum, B.J. Company Profile: History. Available online: https://malolocat.com/about/history / (accessed on 19 May 2021).

107. Spennemann, D.H.R. A Village Site in the Centre of Malolo Lailai Island (Viti Levu). Report to the Fiji Museum; Institute for Land, Water and Society, Charles Sturt University: Albury, NSW, Australia, 2021; p. 8. 
108. Spennemann, D.H.R. Beyond "Preserving the Past for the Future": Contemporary Relevance and Historic Preservation. Crm. J. Herit. Steward. 2011, 8, 7-22.

109. Spennemann, D.H.R. World War II Remains on Central Pacific Islands: Perceptions of Heritage versus Priorities of Preservation. Pac. Rev. 1992, 5, 278-290. [CrossRef]

110. Spennemann, D.H.R. Teacher and Student perceptions of the cultural heritage of the CNMI. An empirical snap-shot. Micrones. J. Humanit. Soc. Sci. 2003, 2, 50-58.

111. Sayers, E.; Spennemann, D.H.R. The Attitudes of Japanese Tourists towards Cultural heritage attractions in the CNMI. Micrones. J. Humanit. Soc. Sci. 2006, 5, 386-397.

112. Usher, L. Mainly about Fiji: Selected Writings, Broadcasts, and Speeches, 1930-1987; Fiji Times Ltd.: Suva, Fiji, 1987.

113. Wikipedia. Malolo Lailai. Available online: https://en.wikipedia.org/wiki/Malolo_Lailai (accessed on 30 November 2020).

114. Tourism Fiji. Plantation Island Resort. Available online: https://www.tourismfiji.com/plantation-island-resort (accessed on 15 February 2021).

115. Ingram, K. Kiwi crafts Fiji Cat. Prof. Skipp. 2013, 94, 60-63.

116. Chambers, C. Reginald Raffe's Journey. Fiji Sun: Suva, Fiji. 10 November 2019, p. 13. Available online: https://www.pressreader. com/fiji / fiji-sun/20191110/281672551760071 (accessed on 22 May 2021).

117. Ross, J. Dick Smith: Man of our Islands. Fiji Sun: Suva, Fiji. 31 July 2012. Available online: https://fijisun.com.fj/2012/07/31 / dick-smith-man-of-our-islands / (accessed on 22 May 2021).

118. Ross, J. The People Who Built Tourism in Fiji. Fiji Sun: Suva, Fiji. 17 June 2015. Available online: https:/ fijisun.com.fj/2015/06/ 17/ the-people-who-built-tourism-in-fiji / (accessed on 22 May 2021).

119. Tuwere, J. Carrying on the Raffe vision for Fiji. Fiji Sun: Suva, Fiji. 19 January 2014. Available online: https://fijisun.com.fj/2014 /01/19/carrying-on-the-raffe-vision-for-fiji/ (accessed on 22 May 2021).

120. Trigger, D.S.; Griffiths, G. Disputed Territories: Land, Culture and Identity in Settler Societies; Hong Kong University Press: Hong Kong, China, 2003.

121. Curthoys, A. White, British, and European: Historicising Identity in Settler Societies; Sydney University Press: Sydney, Australia, 2009.

122. Plantation Island. Fifty \& Fabulous. Available online: https:/ /www.plantationisland.com/plantationturns50/ (accessed on 20 December 2020).

123. Mach, L.; Ponting, J. A nested socio-ecological systems approach to understanding the implications of changing surf-reef governance regimes in Fiji. In Lifestyle Sports and Public Policy; Turner, D., Carnicelli, S., Eds.; Routledge: London, UK, 2017; pp. 137-156.

124. Hollinshead, K. Policy in paradise: The history of incremental politics in the tourism of island-state Fiji. Tourism 2001, 49, 327-348.

125. Veitayaki, J.; Aalbersberg, B.; Tawake, A.; Rupeni, E.; Tabunakawai, K. Mainstreaming Resource Conservation: The Fiji Locally Managed Marine Area Network and Its Influence on National Policy Development; Resource Management in Asia-Pacific Program, Research School of Pacific and Asian Studies, The Australian National University: Canberra, Australia, 2004.

126. Techera, E.J. Safeguarding cultural heritage: Law and policy in Fiji. J. Cult. Herit. 2011, 12, 329-334. [CrossRef]

127. Tyllianakis, E.; Grilli, G.; Gibson, D.; Ferrini, S.; Conejo-Watt, H.; Luisetti, T. Policy options to achieve culturally-aware and environmentally-sustainable tourism in Fiji. Mar. Pollut. Bull. 2019, 148, 107-115. [CrossRef] [PubMed]

128. Rambaldi, G.; Tuivanuavou, S.; Namata, P.; Vanualailai, P.; Rupeni, S.; Rupeni, E. Resource use, development planning, and safeguarding intangible cultural heritage: Lessons from Fiji Islands. Particip. Learn. Action 2006, 54, $28-35$.

129. Mafi, M.; Pratt, S.; Trupp, A. Determining ecotourism satisfaction attributes-a case study of an ecolodge in Fiji. J. Ecotourism 2020, 19, 304-326. [CrossRef]

130. Richards, G. Cultural tourism: A review of recent research and trends. J. Hosp. Tour. Manag. 2018, 36, 12-21. [CrossRef]

131. Royle, S.A. Exploitation and celebration of the heritage of the Irish islands. Ir. Geogr. 2003, 36, 23-31. [CrossRef]

132. Pigliasco, G.C. We branded ourselves long ago: Intangible cultural property and commodification of Fijian firewalking. Oceania 2010, 80, 161-181. [CrossRef]

133. Zhang, G.; Chen, X.; Law, R.; Zhang, M. Sustainability of Heritage Tourism: A Structural Perspective from Cultural Identity and Consumption Intention. Sustainability 2020, 12, 9199. [CrossRef]

134. Ali, B.N.K. Chinese in Fiji; Institute of Pacific Studies, University of the South Pacific: Suva, Fiji, 2002.

135. Ali, B.N.K. Quong Tart and early Chinese businesses in Fiji. J. Pac. Stud. 2005, 28, 78.

136. Campbell, I.C. Across the threshold: Regime change and uncertainty in Tonga 2005-2007. J. Pac. Hist. 2008, 43, 95-109. [CrossRef]

137. A bill for an Act to provide for the recognition and management of places having world heritage values in Fiji. In Bill $n^{\circ} 10$ of 2016; Fiji Parliament: Suva, Fiji, 2016.

138. A bill for an act to give effect to the united nations educational, scientific and cultural organization convention concerning the protection of the world cultural and natural heritage and to provide for the recognition and management of places in Fiji having world heritage values based on the operational guidelines for the implementation of the world heritage convention and for related matters. In Bill $n^{\circ} 3$ of 2021; Fiji Parliament: Suva, Fiji, 2021.

139. Convention Concerning the Protection of the World Cultural and Natural Heritage; United Nations Educational, Scientific and Cultural Organization: Paris, France, 1972. 